\title{
Efficacy of Whole Body Vibration on Post Thyroidectomy Osteoporosis
}

\author{
ZAKARIA M.E. MOAFY, Ph.D.*; ERENY S. WAHBA, Ph.D.* and AMIR A. ABOUTAHOUN, M.Sc.** \\ The Department of Physical Therapy for Surgery, Faculty of Physical Therapy, Cairo University* and \\ Physical Therapy Department, $6^{\text {th }}$ October Hospital**, Giza
}

\begin{abstract}
Purpose: This study was conducted to investigate effect whole body vibration on post thyroidectomy osteoporosis.

Subjects and Methods: Thirty patients with osteoporosis following thyroidectomy were conducted in the present study. All patients with age ranged from 40 to 60 years. They were selected from El-Kasr El-Ainy Hospital and El-Safwa Hospital in Cairo, Egypt.
\end{abstract}

Patients assigned randomly into two Groups (A and B) equal in number: Group (A) fifteen patients received the routine medical treatment (Bisphosphonates, Calcium and Vitamin D) plus whole body vibration for 12 weeks (3 sessions/ week). Group (B) fifteen patients received the recommended routine medical treatment (Bisphosphonates, Calcium and Vitamin D) for 12 weeks.

Evaluations of both groups (A and B) were done before starting the treatment and at the end of study by Dual Energy $\mathrm{X}$-rays (DEXA).

Results: This study showed a statistically significant increase of bone density with percentage of improvement (23.44) in Group (A), compared with Group (B) with percentage of improvement (13.2).

Conclusion: Whole body vibration is an effective modality for improving bone density.

Key Words: Thyroidectomy - Osteoporosis - DEXA - Whole body vibration.

\section{Introduction}

THYROIDECTOMY is the most frequent intervention in endocrine surgery. When performed in specialized centers, the operation is safe with low morbidity and $0 \%$ mortality [1]

After the removal of a thyroid, patients usually take a prescribed oral synthetic thyroid hormone

Correspondence to: Dr. Zakaria M.E. Moafy, The Department of Physical Therapy for Surgery, Faculty of Physical Therapy, Cairo University [levothyroxine (synthroid)] to prevent hypothyroidism [2].

However, TSH suppression was associated with a significantly increased risk of adverse events. Women with suppressed TSH levels were three times as likely to develop osteoporosis compared with those whose levels were not suppressed. Even after adjusting for age-a major factor in osteoporosis-TSH remained a strong predictor for the condition. The risk of osteoporosis appeared to taper with less TSH suppression, but risk of recurrence remained the same. TSH suppression was not linked with a significantly increased risk of atrial fibrillation [9].

Considerable controversy surrounds the role that thyroid disorders play in exacerbating bone loss and the risk of osteoporotic fractures. Bone mass is generally said to be reduced with hyperthyroidism and in many the secretion of calcitonin is dramatically reduced by total or subtotal thyroidectomy and/or radioiodine therapy, and calcitonin deficiency has also been postulated to cause osteopenia [6]

As a physiotherapy method, Whole-Body Vibration (WBV) treatment produces a vibratory stimulation of the entire body for patients standing on a vibrating platform, due to sinusoidal oscillations in vertical or rotational mode. Recent studies have reported that WBV may increase bone formation in animal models, young adults, and children with low Bone Mineral Density (BMD) or physical impairments, promote neuromuscular adaptation and increase muscle strength [11]

\section{Subjects and Methods}

This study was started from June 2016 till January 2017 at El-Kasr El-Ainy Hospital and ElSafwa Hospital in Cairo, Egypt. 
Subjects: Thirty patients who had thyroidectomy since 6 months and suffered from osteoporosis. They were selected from El-Kasr El-Ainy Hospital and El-Safwa Hospital and patients were assigned randomly into two groups of equal numbers, (Group A and Group B).

Inclusive criteria: All patients participated in this study were males and females, age ranged between 40 and 60 years, had thyroidectomy since 6 months, suffered from osteoporosis in femur and spine and have sufficient cognition and education enough to understand the requirements of the study.

Exclusive criteria: All patients with thrombosis, had acute inflammation, received pharmacologic intervention for osteoporosis before the starting of treatment, had history of severe musculoskeletal problems, received immunosuppressant, anticonvulsants therapy, suffered from psychological problems or who were alcoholic drinkers were excluded from this study.

Equipment: The study equipment were divided into two different categories, measuring and therapeutic equipment.

Measuring equipment: Evaluation the bone mineral density using Dual Energy X-ray Absorptiometry (DEXA).

Treatment equipment: Whole body vibration apparatus (model power plate-my $5 \mathrm{tm}$, made in United States) with frequency $30-40 \mathrm{~Hz}$ was used for whole body vibration program by reciprocating vertical displacements on the left and right side of a fulcrum.

Procedure of application: The subjects will be informed about the nature of the study; each subject signed consent form before participating in the study. Treatment time of the present study was given in the period of 12 weeks.

- Group A (study group): Patients in study group treated with WBV 10min, 3 times weekly on a platform set to vibrate at $(3 \mathrm{OHz}$ and intensity $5 \mathrm{~mm}$ ) with treatment medical treatment intake (12 weeks).

- Group B (control group): Patients in control group receive routine medication during the duration of the study (12 weeks).

Patients in control group receive routine medication during the duration of the study. (12 weeks):

Ethical consideration: Confidentiality was assured by signing the consent form and respect to all patients was ascertained through explaining the objectives of the study and its benefits. The study was approved by Ethical Committee of Faculty of Physical Therapy, Cairo University. (P. T. REC/0 12/001000).

\section{Results}

Comparing the general characteristics of the subjects of both groups revealed that there was no significance difference between both groups in the mean age $(p=0.4)$.

The sex distribution of the control group revealed that there were 5 males with reported percentage of $33 \%$ and 10 females with reported percentage of $67 \%$ as shown in (Table 1).

The mean \pm SD age of the control group was $51 \pm 5.87$ years, with maximum value of 59 years and minimum value of 41 years. There was no significant difference between both groups in the mean age values $(p=0.4)$. Table (2).

The mean \pm SD BMD pre-treatment of study group was $2.09 \pm 0.18 \mathrm{~g} / \mathrm{cm}$ and that post-treatment was $1.6 \pm 0.11 \mathrm{~g} / \mathrm{cm}$. The mean difference between pre and post-treatment was $0.49 \mathrm{~g} / \mathrm{cm}$ and the percent of improvement was $23.44 \%$. There was a significant increase in the BMD in the study group post-treatment compared with pre-treatment $(p=0.0001)$. (Table 3$)$.

The mean \pm SD BMD pre-treatment of control group was $-2.12 \pm 0.31 \mathrm{~g} / \mathrm{cm}$ and that post-treatment was $-1.84 \pm 0.3 \mathrm{~g} / \mathrm{cm}^{2}$. The mean differencę between pre and post-treatment was $-0.28 \mathrm{~g} / \mathrm{cm}$ and the percent of improvement was $13.2 \%$. There was a significant increase in the BMD in the control group post-treatment compared with pre-treatment $(p=0.0001)$.

The mean \pm SD BMD pest-treatment of study group was $-1.6 \pm 0.11 \mathrm{~g} / \mathrm{cm}_{2}$ and that of control group was $-1.84 \pm 0.3 \mathrm{~g} / \mathrm{cm}^{2}$. The męan difference between both groups was $0.24 \mathrm{~g} / \mathrm{cm}$. There was a significant increase in the BMD in the study group compared with control groups post-treatment ( $p=$ 0.009). (Table 4).

Table (1): Frequency distribution of sex in both groups (study and control).

\begin{tabular}{lccrrr}
\hline & \multicolumn{2}{c}{ Study group } & & \multicolumn{2}{c}{ Control group } \\
\cline { 2 - 3 } \cline { 5 - 6 } & Males & Females & & Males & Females \\
\hline No. & $8(53 \%)$ & $7(47 \%)$ & & $5(33 \%)$ & $10(67 \%)$ \\
\hline Total & $15(100 \%)$ & & $15(100 \%)$ \\
\hline
\end{tabular}


Table (2): Statistical analysis of mean age and pre-treatment mean values of BMD of study and control groups.

\begin{tabular}{llc}
\hline & Study group & Control group \\
\hline X \pm SD & $49.13 \pm 6.25$ & $51 \pm 5.87$ \\
Minimum & 40 & 41 \\
Maximum & 59 & 59 \\
MD & -1.87 \\
$t$-value & -0.84 \\
$p$-value & 0.4 \\
Significance & NS \\
$\bar{x} \quad:$ Mean. & \multicolumn{2}{c}{$t$-value : Unpaired $t$-value. } \\
SD : Standard Deviation. & $p$-value : Probability value. \\
MD : Mean Difference. & NS $:$ Non Significant.
\end{tabular}

Table (3): Statistical comparison between pre and posttreatment mean values of BMD of control and study group.

\begin{tabular}{|c|c|c|c|c|c|c|}
\hline & $\begin{array}{l}\mathrm{BMD}_{2} \\
\left(\mathrm{~g} / \mathrm{cm}^{2}\right) \\
\mathrm{X} \pm \mathrm{SD}\end{array}$ & MD & $\begin{array}{c}\text { Percent of } \\
\text { improve- } \\
\text { ment }\end{array}$ & $\begin{array}{c}t- \\
\text { value }\end{array}$ & $\begin{array}{c}p- \\
\text { value }\end{array}$ & Sig \\
\hline $\begin{array}{l}\text { Study } \\
\text { group: } \\
\text { Pre } \\
\text { Post }\end{array}$ & $\begin{array}{l}-2.09 \pm 0.18 \\
-1.6 \pm 0.11\end{array}$ & -0.49 & 23.44 & -14.03 & 0.0001 & S \\
\hline $\begin{array}{l}\text { Control } \\
\text { group: } \\
\text { Pre } \\
\text { Post }\end{array}$ & $\begin{array}{l}-2.12 \pm 0.31 \\
-1.84 \pm 0.3\end{array}$ & -0.28 & 13.2 & -9.87 & 0.0001 & S \\
\hline 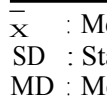 & $\begin{array}{l}\text { andard Deviati } \\
\text { an Difference. }\end{array}$ & & $\begin{array}{l}t \text {-va } \\
p \text {-v } \\
\text { NS }\end{array}$ & $\begin{array}{r}\text { alue : Un } \\
\text { ralue : Pro } \\
\text { : No }\end{array}$ & $\begin{array}{l}\text { paired } t-\mathrm{v} \\
\text { bability } \\
\text { n Signific }\end{array}$ & $\begin{array}{l}\text { value. } \\
\text { value. } \\
\text { cant. }\end{array}$ \\
\hline
\end{tabular}

Table (4): Statistical comparison between post-treatment mean values of BMD of study and control groups.

\begin{tabular}{lccccc}
\hline & $\begin{array}{c}\text { BMD }\left(\mathrm{g} / \mathrm{cm}^{2}\right) \\
\mathrm{X} \pm \mathrm{SD}\end{array}$ & MD & $\begin{array}{c}t- \\
\text { value }\end{array}$ & $\begin{array}{c}p \text { - } \\
\text { value }\end{array}$ & Sig. \\
\hline Study group & $-1.6 \pm 0.11$ & 0.24 & 2.8 & 0.009 & $\mathrm{~S}$ \\
Control group & $-1.84 \pm 0.3$ & & & & \\
\hline$\overline{\mathrm{X}}$ : Mean. & \multicolumn{3}{c}{$t$-value : Unpaired $t$-value. } \\
SD : Standard Deviation. & \multicolumn{2}{c}{$p$-value : Probability value. } \\
MD : Mean Difference. & NS & : Non Significant.
\end{tabular}

\section{Discussion}

The current study was designed to evaluate the therapeutic efficacy of whole body vibration in treatment of osteoporosis following thyroidectomy using the parameters involved DEXA as a method of evaluation was measured at different times:

- Pre-treatment application (before treatment).

- Post-treatment application (after 12 weeks of treatment).

Whole-Body Vibration (WBV) has received much attention as a potential anti osteoporotic intervention in recent years. In experimental animal models, WBV was found to lead to anabolic bone changes. Based on these data and the availability of many different WBV platforms in North America and Europe, optimistic claims that these benefits may translate to humans have been made within the scientific community and in the media. Such claim quickly proliferated to today's information savvy general population and has left many clinicians and patients wondering about the role of WBV in osteoporosis prevention and/or treatment [7].

WBV may provide an even greater stimulus for maintaining or improving bone health (Gusi et al., [5]). The WBV trained 3d weekly with six 1min exposures (standing with knees flexed to 60on a platform set at $12.6 \mathrm{~Hz}$ and $3 \mathrm{~mm}$ ) while the walking group exercised for $3 \mathrm{~d}$ weekly. The WBV group significantly increased BMD of the femoral neck [10]

Results on WBV therapies are not entirely clear; some studies have shown increases in BMC at the lumbar spine (Dalen et al., [3]), and areal BMD at the femur (Ruck et al., [8]) and (Gilsanz et al., [4]) and the spine.

Therapeutic results of the significant outcomes of Whole body vibration are summarized as follow:

1- Improving bone mass density.

2- Improving leg muscles strength.

3- Improving muscle power and balance.

Positive clinical efficiency of whole body vibration on bone mineral dinesty:

This concept was supported by some previous studies and past literatures that conducted by following authors $[4,10,12]$ :

- Torvinen et al., [10] concluded that 3 to 5 times weekly on a platform set to vibrate at 25 to 45 $\mathrm{Hz}$ in ascending order. In spite of a $7.8 \%$ gain in jump height, bone mineral content, serum markers of bone turnover, and estimates of bone mass and structure were not affected at any skeletal site. The subjects in the WBV group assumed a series of body positions during the 4-min exposure.

- Gilsanz et al., [4] suggested that several orders of magnitude below that associated with vigorous exercise, increased bone and muscle mass in the weight-bearing skeleton of young adult females with low BMD.

-Wysocki et al., [12] low amplitude high-frequency Whole-Body Vibration (WBV) training is recently receiving much attention for treating low levels of bone mass. 


\section{Conclusion:}

From the previous results and discussions, it could be concluded that pulsed Whole body vibration improves bone mineral density of patient suffer from osteoporotic changes post thyroidectomy.

\section{References}

1- BLISS R., GAUGER P. and DELBRIDGE L.: Surgeon's approach to the thyroid gland: Surgical anatomy and the importance of technique. World J. Surg., 24: 891-7, 2000.

2- BOGAERTS A., DELECLUSE C., CLAESSENS A.L. and COUDYZER W.: Impact of whole-body vibration training versus fitness training on muscle strength and muscle mass in older men: A 1-year randomized controlled trial". The Journals of Gerontology, 2007.

3- DALEN Y., SÄÄF M., NYRÉN S., MATTSSON E., HAGLUND-AKERLIND Y. and KLEFBECK B.: Observations of four children with severe cerebral palsy using a novel dynamic platform. A case report. Adv. Physiother., 14: 132-9, 2012.

4- GILSANZ V., WREN T.A., SANCHEZ M., DOREY F., JUDEX S. and RUBIN C.: Low-level, high-frequency mechanical signals enhance musculoskeletal development of young women with low BMD. J. Bone Miner. Res., 21: 1464-74, 2006.

5- GUSI N., RAIMUNDO A. and LEAL A.: Low-frequency vibratory exercise reduces the risk of bone fracture more than walking: A randomized controlled trial. B.M.C. Musculoskeletal. Disorder, 7: 92, 2006.

6- LI J., LIN J., LIU H. and CHANG W.: Cytokine release from osteoblasts in response to different intensities of pulsed electromagnetic field stimulation. Electromagn. Biol. Med., 26 (3): 153-65, 2007.

7- RUBIN C., JUDEX S. and QIN Y.X.: Low-level mechanical signals and their potential as a non-pharmacological intervention for osteoporosis. Age Ageing, 35: ii32-ii36, 2006.

8- RUCK J., CHABOT G. and RAUCH F.: Vibration treatment in cerebral palsy: A randomized controlled pilot study. J. Musculoskeletal. Neuronal. Interact, 10: 77-83, 2010.

9- SMITH A., WANG L. and PALMER F.: TSH suppression increases the risk of osteoporosis without changing recurrence in non-high risk patients with thyroid carcinoma. Presented at the 83 rd Annual Meeting of the American Thyroid Association, October 16-20, 2013, in San Juan, Puerto Rico. Thyroid October 2013, 23 (S1): A-115-A121. Abstract 5, 2013.

10- TORVINEN S.P., KANNUS H. and SIEVANEN: Effect of 8-month vertical whole body vibration on bone, muscle performance, and body balance: A randomized control study. J. Bone Miner. Res., 18: 876Y884, 2003.

11- TOTOSY De ZEPETNEK J.O., GIANGREGORIO L.M. and CRAVEN B.C.: Whole body vibration as potential intervention for people with low bone mineral density and osteoporosis: A review. J. Rehabil. Res., 46: 529-42, 2009.

12-WYSOCKI A., BUTLER M., SHAMLIYAN T. and KANE R.L.: Whole-body vibration therapy for osteoporosis: state of the science. Ann. Intern. Med., 155 (680-686): W206-W613, 2011. 


\section{فاعلية إهتزاز الجسم كله على هشاشة العظام بعد إستئصال الغدة الدرقية الهية}

الهدف من البحث: آجريت هذه الدراسة لمعرفة تآثير إهتزاز الجسم كله على المرضى الذين يعانون من هشاشة العظام عقب إستئصال

الغدة الدرقية.

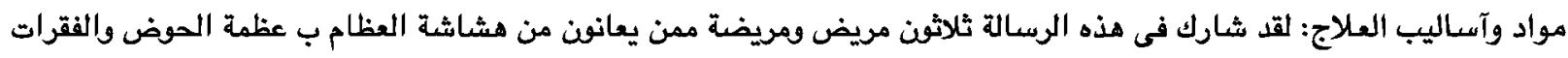

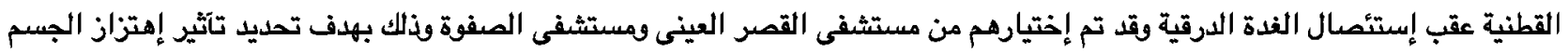

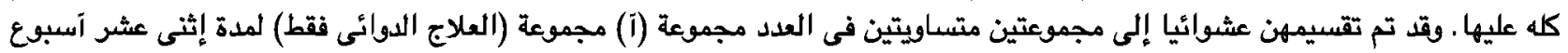

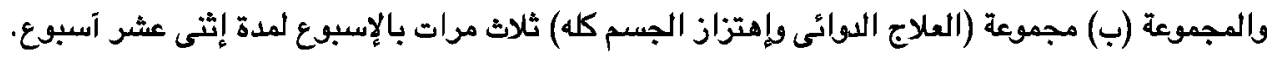

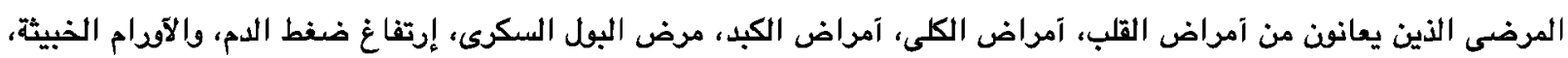

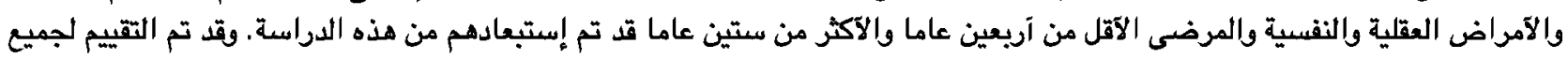

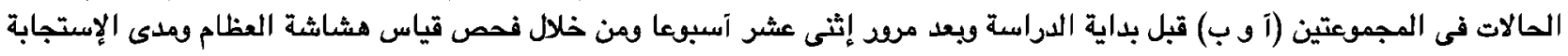

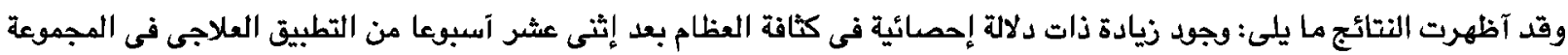

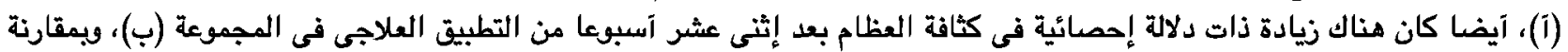

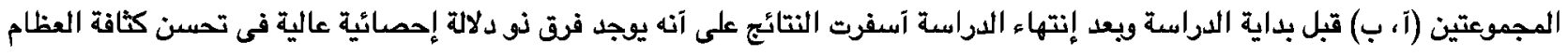

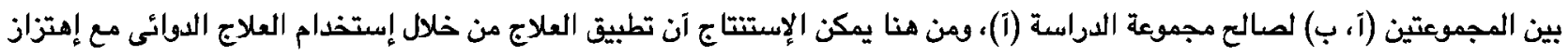

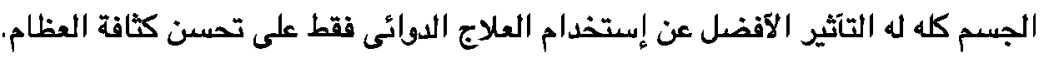
ولقد إشتملت هذه الدراسة على إثنى عشر (r) مرجعا تم ترتيبهم ترتيب آبجديا. 